\title{
The Connotation and Time Value of the Red Style of the Proletarian Internationalism in the Old Revolutionary Area -Taking Sichuan as an Example
}

\author{
Junfeng Zhang \\ School of Intelligent Manufacturing, Sichuan University of Arts and Science, Dazhou, China \\ Email: zjingming2019@sina. Com
}

How to cite this paper: Zhang, J.F. (2020) The Connotation and Time Value of the Red Style of the Proletarian Internationalism in the Old Revolutionary Area-Taking Sichuan as an Example. Open Access Library Journal, 7: e6798.

https://doi.org/10.4236/oalib.1106798

Received: September 7, 2020

Accepted: October 9, 2020

Published: October 12, 2020

Copyright $\odot 2020$ by author(s) and Open Access Library Inc.

This work is licensed under the Creative Commons Attribution International License (CC BY 4.0).

http://creativecommons.org/licenses/by/4.0/

\begin{abstract}
In the course of the Chinese revolution, reform and construction, the people of Sichuan have always taken an active part in and devoted themselves to the various causes of the country, and a large number of typical proletarian internationalism have emerged in the baptism of blood and fire. The Red family style embodied in these groups of revolutionaries is still of outstanding value in the new era. The purpose of this paper is to summarize the characteristics and educational value of the red family style of the proletarian internationalism. In the study, mainly by reference, comparison, analysis and other methods. Based on the research, this paper holds that the red family style of Sichuan proletarian internationalism is characterized by firm belief, patriotism for the people, filial piety, frugality and honest struggle. People attach importance to and inherit the red family style that is conducive to carrying forward and practicing China's core socialist values.
\end{abstract}

\section{Subject Areas \\ Education, Politics}

\section{Keywords}

Sichuan, Proletarian Internationalism, Red Family Style, Socialist Core Values

\section{Introduction}

Chinese National Training has a long history and is a unique landscape in the history of Chinese culture, embodying the wisdom and strength of the Chinese nation, it has strong vitality and universal value that transcends the times, and 
plays an important role in shaping individual ideal personality in Chinese history. Therefore, General Secretary Xi Jinping stressed: "No matter how big changes have taken place in the times, no matter how big changes have taken place in the pattern of life, we must attach importance to family building, family education, and family style" [1]. Red Family style is a moral fashion formed in the family by the old proletarian internationalism in the course of Chinese revolution, reform and construction, and is the wisdom crystallization of the CPC members' practice of cultivating one's body and keeping one's family in the family. As a spiritual force, the red family style continues the unique beliefs of the communists and the fine traditions of the country, the nation and the family. It constantly nourishes and inspires generations of communists not to forget their original intentions and to take up their mission, it has become an important part of the socialist culture with Chinese characteristics, the great spiritual pedigree and fine tradition of the Chinese communists. The Red family style of the proletarian internationalism is an important component of the red family style and red genes of the Chinese communists. The study of the connotation and the time value of the red family style of the Sichuan native proletarian internationalism group is a further excavation of the red cultural resources with Sichuan characteristics, which is beneficial to "enriching the mind with culture" and "enriching the mind with virtue", to the new era student's socialism core values education and so on all has the enormous benefit.

\section{The Connotation of the Red Family Style of Sichuan Proletarian Internationalism}

The connotation of the Red Ethos of the proletarian internationalism, the people of Sichuan have always actively participated in and devoted themselves to the various undertakings of the country in the course of the Chinese revolution, reform and construction, in the baptism of fire and blood, a great number of representatives of the proletarian internationalism emerged. In December 1932, the fourth front army came to East River and established Communist-controlled China Shaanxi. Dazhou is the heart of Communist-controlled China. The people of Dazhou took an active part in the revolutionary cause of the Party and the Red Army, with 80,000 people participating in the military revolution. More than 20,000 people gave their precious lives in the desperate struggle against the enemy. In 1935, after the Red Fourth Front army left the Sichuan-Shaanxi Soviet area, the Kuomintang Army and the Home Returning Regiment retaliated crazily against the Red Army family. It was the great sacrifice of these faithful revolutionary ancestors and their families that brought about the constant growth and development of the Party and the Red Army, and finally the victory of the revolution. After the founding of the People's Republic, Marshal Xu Xiangqian, who led the people of Dazhou in the Soviet area of Sichuan and Shaanxi in their bloody struggle, spoke highly of the People's contribution to the revolution: "The people there, working hard and making heroic sacrifices, have contributed all the strength they can to the victory of the Chinese revolution. The survival, development and 
expansion of the red four front army cannot be separated from the strong support of the people in the Sichuan-Shaanxi base area. Thousands of heroic sons and daughters of the people of Sichuan and Shaanxi laid down their precious lives in the struggle to establish and defend the base areas" [2]. As of today, the number of Sichuan proletarian internationalism who have worked tirelessly for the cause of the Party and the people cannot be counted, we only take the typical representative of them as an example to study the red family style that they have condensed and passed on. Typical proletarian internationalism from Sichuan are Deng Xiaoping, Zhu De, Liu Bocheng, Zhang Aiping, Wang Weizhou, Chen Bojun, Xiang Shouzhi, Wei tradition, Li Zhongquan, Wang Dinglie, Wan Chengzhang, Li Linsen and so on.

\subsection{Faith Is Fundamental}

Communists are revolutionaries who believe in Marxism. Guided by the truth of Marxism, the Communists discovered the law of the development of human society and the root of the ruin of the old China. Then, aiming at Communism and socialism, they led hundreds of millions of people through a series of deadly battles with the Kuomintang reactionaries and the Empire of Japan, finally establishing an independent New China in 1949. The Chinese people have since stood up, "home" is no longer toppled, the nation is no longer ravaged. It can be said that it was the truth of Marxism and the blood of countless revolutionaries who gave their lives for the founding of New China and the ideal of communism that forged our new "Great Wall of China". The establishment of the new China and the rising of the powerful country also proved the correctness of Marxist truth and the greatness of the Chinese communists. Therefore, from the practice or from the emotional and psychological, the communist belief in Marxism is extremely firm. A firm belief in Marxism is, so to speak, the defining characteristic of all proletarian internationalism. Their strong belief in Marxism is reflected not only in their work practices abroad, but also in their family life and the education of their children. So does a proletarian internationalism from Dazhou. Such as Dazhou's founding generals, Lee Jung-Kuan and man Sung-Chang. Li Zhongquan joined the Red Army in 1931. Under the influence of Li Zhongquan, his family also took part in the revolution. For example, his eldest brother, Li Zhongpan, was the chairman of the township Soviet, his fifth sister, Li Zhongzhen, was a woman chairman, and his parents, his second brother, Li Zhongchi, and his fourth brother, Li Zhongbai, were all transporting grain for the Red Army and participating in the revolution. During the Long March, "my father jumped off a cliff to protect the Red Army, my elder brother was killed by the 'left leaning' route, and my mother died on the Long March road after using the 'Foot binding' to 'measure' the snowy mountains and grasslands" [3]. General Li Zhongquan's whole family took part in the Long March. Only four brothers and sisters completed the Long March. All other relatives were killed. How firmly his family believed in communism! 


\subsection{Patriotism Is the Prerequisite for the People}

Serving the people is the consistent aim of the Communist Party. During the revolutionary period, the Party always taught my party members and soldiers to fight for the people and the country. After the founding of the People's Republic, we established the Government of the People's Republic of China, the People's Army, and various people's organs and organizations, it's about serving the people. Our proletarian internationalism has faithfully served this purpose. So did the Dazhou Revolutionaries. Many revolutionaries of Dazhou origin are selfless in their work, dedicating all their efforts to the country and the people. General Zhang Aiping went to Shanghai in 1929 to join the revolution, and after that, the Dead Tone, the civil war, the building of a strong military enterprise, more than 50 years have not returned to his hometown, only in 1987 to visit the work of Sichuan on the way back to his hometown. So did the Dazhou generals to Morishi and Wang Dinglie. Xiang Shouzhi, a former commander of the Nanjing Military Region, was not enjoying his leisure before and after his retirement, but playing with his remaining heat, being enthusiastic and participating in public welfare undertakings. "When the Nanjing Charity Association was founded, the old general generously took $\$ 1000$ from his own savings over the years and gave it a start-up fund. In the summer and autumn of 1999, when the Yangtze, Pearl and Heilongjiang rivers were flooded, the old general was so anxious that he could not eat or sleep. He took the lead in giving money and materials in response to the call of the Charity General Association. When funds were scarce for the construction of Railways, road widening, hydropower stations and reservoirs in his hometown in Xuanhan County, Sichuan, he made many donations to the old people and encouraged them to do so. As far as we know, over the past three years, the foundation has been to donate as much as 50,000 yuan to the elderly for social welfare" [4].

\subsection{Filial Piety, Frugality and Simplicity Is Not Only an Excellent Traditional Virtue of the Chinese Nation, but Also an Excellent Tradition of the Communist Party of China}

Dazhou proletarian internationalism from Daba Mountains is also practitioners of filial piety and frugality. Many generals not only practice this philosophy themselves, but also pass on this fine style to their children. When General Wan Chengzhang's daughter described their family's frugal, low-key style, "In the 1960s, when the economy was struggling, my mother was bloated from malnutrition, but she still didn't take advantage of my father's position," he said. And for those who need help, even unknown beggars always do their best. When we were going through her things after she died, we also found some unsigned donation slips. Mother's life is very simple, never pay attention to food and clothing, wearing clothes are mostly their own sewing, rarely buy new clothes, a turban on wearing a few decades. She is very strict with our children. She never allows them to be ostentatious and special. She has to rely on her own efforts in everything. She has to do things conscientiously and conscientiously. She has to 
be worthy of the party, the country, the people, the parents and herself [5], the words and deeds of her mother and her father became our motto and a Lifelong Role Model [5]. Wan Yulan (the retired Wan Yulan was deputy director of planning and finance of the Qingdao Post and Telecommunications Bureau and a senior Accountant) was herself a close follower of her parents' teachings, when she and her husband, Tang Zhaowen, retired as party secretary and chief engineer of the Qingdao Bus Company, lived in "a small, old house on Longtan Road, far from what one might expect from the children of a military cadre". An old-fashioned hand-held sewing machine takes up one-tenth of the bedroom area, but it is her daily helper. She not only sews and mends her own clothes, but also makes many of the costumes of the community art team. The contrast between their simple life and their family background makes it hard for many people to believe. And this is a reflection of Dazhou's proletarian internationalism to filial piety and frugality.

\subsection{Characterized by a Struggle for Probity}

Incorruptibility struggle is another fine style of the Communists. During the revolutionary war, the vast number of proletarian internationalism worked honestly and courageously, winning the wholehearted support of the people. After the founding of the People's Republic of China, proletarian internationalism took up leadership positions one after another, and their living standards improved greatly. The same is true of the revolutionaries of Dazhou, who lived by example and passed on these virtues to their children. In 1987, General Zhang Aiping returned to his hometown for a visit. The local government arranged for the general's relatives to be received together. When Zhang Aiping saw this, he did not agree, but "they all managed to persuade him to accept the arrangement, in which case Comrade Li Youlan, the wife of the old general, always sided with the chief. The old general was so honest and upright that he really got angry that day, which made all the comrades in his entourage tremble with fear, and eventually all his relatives went home, at the weekend, he took it easy and went home to visit his relatives and friends [6]. His clean, low-key style has been inherited by his descendants. Another Dazhou revolutionary represents the Cao Wei tradition. Wei Tradition, Dazhou Tongchuan district people, joined the Revolution in 1925, later People's Liberation Army Academy of Art Dean, is a well-known Confucian generals. Because of Cao Wei's reputation for traditional calligraphy, many people begged him to write, and he gladly took up any legitimate demand for the benefit of the people, without taking any money. And the improper request, although is the family member, also can flatly refuse." The Cao Wei tradition has strict principles, and so does the inscription, and the content of the question remains unasked. Once, a fellow Sichuanese came to Cao Wei and asked him to write the words "authentic Sichuan food" for a restaurant he was opening somewhere in the capital in order to attract more customers. Wei tradition with a smile, declined: "fellow-townsman, sorry, I cannot write these words casually, I am responsible to the customer" [7], who knows if you are authentic; Besides, he 
teaches his family to strive for probity all the time. Now that life is easier, who doesn't want to modernize their home, but Wei Lao has his own view. The most dangerous aspect of the party's emphasis on clean government is corruption. The party has a fine tradition in matters of probity, one of which is the spirit of hard struggle advocated by the party for many years. So he often reminded the children of the old saying, "the new three years, the old three years, the mending three years."

\section{The Practical Significance of the Red Family Style of the Proletarian Internationalism Group}

\subsection{It Is Conducive to Providing a Reference and a Benchmark for the Building of the Family Style of Contemporary Party Members and Cadres since the Communist Party of China Is the Ruling Party, a Considerable Number of Party Members Are State Cadres}

Family style is connected with politics style. The family style of a party member cadre has a great influence on his conduct of government. Since the 18th anniversary of the founding of the People's Republic of China in 1949, party members and cadres at all levels have often been imprisoned for corruption. Because the family style is mainly the family moral standard, belongs to the private morals domain, at present our party has not yet regarding this aspect rigid standard. Therefore, the red family style of the proletarian internationalism group has an important demonstration and reference value. With the development of the Times, the red family style with the connotations of firm belief, patriotism for the people, filial piety, frugality and honest struggle of the proletarian internationalism will not be out of date, but will be further enriched and developed. All these can provide a useful reference for the majority of Contemporary Party members and cadres to deal with family problems.

\subsection{Conducive to the Cultivation and Promotion of Socialist Core Values}

Contributing to the cultivation and promotion of the socialist core values the socialist core values are the core objectives of the ideological construction and the construction of spiritual civilization in China in the new era, it is a matter of the party and the country's peace, stability, development and competition. However, in the process of cultivating and carrying forward the socialist core values, there are some difficulties such as weak infectivity, lack of interactivity, and lack of daily life. The Red family style of the proletarian internationalism can play a unique role in this confusion. The Red Family style is the embodiment of the belief and national feelings of the proletarian internationalism group in the family, which is intrinsically coupled with the ideological connotation of the socialist core values. At the same time, because the red family style is the moral standard formed by the revolutionary group in the long years and family life, its rich, life-oriented characteristics can effectively overcome the popular socialist core 
values of the impact of education, lack of life-oriented shortcomings. Therefore, red family style has great recessive educational value of socialist core values and can become an important carrier of effective education of socialist core values.

\subsection{It Is Conducive to Promoting Contemporary Family Moral Education and Building a Harmonious Family}

"The family is the smallest country, and the state is the largest country." Since ancient times, China has always attached great importance to the moral education of the family. The family is like the "cell" of society. From the individual level, family moral education has the function of promoting individual socialization; from the moral level itself, family moral education has the function of maintaining and promoting the development of moral culture; from the social and national level, family moral education plays an important role in maintaining social stability and harmony and promoting social development. However, with the social changes, compared with the traditional society, the structure and role of the contemporary family has changed a lot. For a period of time, we did not pay enough attention to the moral education of the family, resulting in many moral problems of the family. The Red family style can not only serve as a model of the construction of the family style of the Party members and leading cadres, but also can be extended to the whole society, as a vivid example of the construction of Socialist family morality. Families can learn from the red family style, learn to strengthen the concept and methods of family members, constantly promote the accumulation and development of their own family moral education.

\subsection{It Is a Characteristic of Our Country to Strengthen the Actual Effect of Ideological and Political Education of Students}

For a long time, the actual effect of our ideological and political education at all levels is quite strong. However, with the development of globalization, market economy and information technology, the thoughts of Western money worship, individualism, hedonism and historical nihilism spread to our country, to a certain extent, eroding the effect of our ideological and political education. How to deal with these challenges has become the focus of our research. From the perspective of ideological and Political Education, the implementation of ideological and Political Education needs the integration of educational subject, educational object, educational carrier, educational environment and other factors. At the National Conference on Ideological and political work in colleges and universities, General Secretary Xi Jinping proposed that ideological and political education should be carried through the whole process of education and teaching, and that it should be carried out in all-round way. Therefore, the red family style of the proletarian internationalism can become the content and carrier of ideological and political education in colleges and universities. As Sichuan is one of the old revolutionary areas, one of the characteristics of Sichuan's historical culture is red culture. All districts and counties in Sichuan Province are rich in red cul- 
tural relics, memorials and documents. Sichuan strong regional red characters, red family style to cultivate students, will let students feel, so many heroes, role models in my side, how did they build a career? What do they think about faith and confusion? Give full play to the role of the red family, from the emotional, psychological enhancement of students to love the identification of the Patriotic Party.

\section{Foundation Project}

Project of Development Research Center of Sichuan Old Revolutionary Base Area (Item number: SLQ2019B-18); 2020 Humanities and Social Sciences Research Project of Ministry of Education (University Counselor Research) (Item number: 20JDSZ3148); Project supported by Sichuan University of Arts and Sciences (Item number: 2019TZ003Z); Special Project of Ideological and Political Work of Sichuan University of Arts and Sciences (Item number: 2018SZ001Y).

\section{Conflicts of Interest}

The author declares no conflicts of interest regarding the publication of this paper.

\section{References}

[1] Xi, J.P. (2015) We Should Attach Importance to Family Construction No Matter How the Times Change.

http://politics.people.com.cn/n/2015/0217/c70731-26580958.html

[2] Xu, X.Q. (1984) Historical Review. PLA Press, Beijing, 99.

[3] Liu, S.C. (2012) Man Men Revolution, Glory Forever in History-the Long March of General Li Zhongquan and His Family of Nine. Construction of China's Old Districts, No. 7, 58 .

[4] Lu, J. (2001) General Morishi, Advisor to the Nanjing Charity General Association, a Veteran General with a Passion for Charity. Reform and Opening up, No. 11, 37.

[5] Deng, D.J. (2013) General Zhang Aiping. Secretarial Work, No. 7, 46.

[6] Wu, H.J. (1998) Left the Ink on the Earth, Remember the Calligrapher General Wei Tradition. Sichuan Party History, No. 1, 34.

[7] Ji, H.Y. and Tai, P.C. (1988) Courage in Tackling Key Problems, Poems and Books Encourage Future Generations-Interview with Veteran General Wei Tradition. Research on Ideological and Political Work, No. 11, 40. 